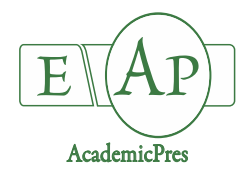

Ianovici $\mathrm{N}$ and Birsan M-V (2020)

Notulae Botanicae Horti Agrobotanici Cluj-Napoca 48(2):752-769

DOI: $10.15835 /$ nbha48211862

Research Article

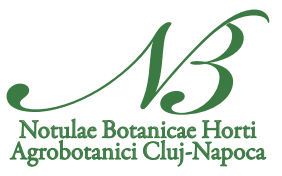

\title{
The influence of meteorological factors on the dynamic of Ambrosia artemisiifolia pollen in an invaded area
}

\author{
Nicoleta IANOVICI ${ }^{1 *}$, Marius-Victor BÎRSAN ${ }^{2}$ \\ ${ }^{1}$ West University of Timisoara, Department of Biology-Chemistry, Faculty of Chemistry, Biology, Geography, 16 Pestalozzi Street, \\ Timisoara, Romania; nicoleta.ianovici@e-uvt.ro ( ${ }^{*}$ corresponding author) \\ ${ }^{2}$ Meteo Romania (National Meteorological Administration), Department of Research and Infrastructure Projects. Sos. Bucuresti-Ploiesti \\ 97, 013686 Bucharest, Romania; marius.birsan@gmail.com
}

\begin{abstract}
The aim of the present study was to analyse the effect of weather conditions on Ambrosia artemisiifolia air pollen concentrations in the highly invaded area of western Romania. The investigation of Ambrosia pollen concentrations was carried out for a period of ten years by means of the volumetric method. Ambrosia pollen concentrations had increasing trend over study period. The results of cluster analysis show that two main groups were identified: group A, with lower SPI and group B, with much higher SPI. The statistical correlation between pollen concentrations and meteorological factors was determined by Pearson's test. The relationships between Ambrosia pollen concentrations and meteorological parameters, were further assessed using multiple linear regression techniques. The pollen emissions are affected by meteorological factors in the main pollen season. Our results suggest that the abundance of Ambrosia artemisiifolia in western Romania is massive. The Ambrosia pollen load of Timisoara is most important between 15 August - 15 September. Consequently, this is the most dangerous period of the year for allergic reactions. The investigation of Ambrosia pollen behaviour in the atmosphere is a compulsory step for measures to stop the spread and establishing control. Ambrosia pollen represents a major health problem and can be considered the main aero allergenic plant pollen in our region.
\end{abstract}

Keywords: aeroallergen; main pollen season (MPS); seasonal pollen index (SPI)

\section{Introduction}

Ambrosia artemisiffolia (short or common, annual ragweed) is an annual monoecious weed and has become a spreading neophyte in Europe. A. artemisiifolia is anemophilous, contrary to most Asteraceae. It is an invasive and noxious plant, an important weed in agriculture and source of allergenic pollen (Skjøth et al., 2010; Makra et al., 2015; Sikoparija et al., 2017).

Common ragweed, which is native to North America, can also be found on other continents, including Asia, Australia, Africa, and South America (Essl et al., 2015). In European areas most contaminated are Hungary, Romania, Serbia, Croatia, Ukraine, parts of France, northern Italy, but it is also spreading in 
Switzerland, Austria, the Czech Republic, Slovakia, Poland, Germany, Georgia and Bulgaria (Stepalska et al., 2008; Smith et al., 2013). Ambrosia's pollen is a major aeroallergen and is becoming an extremely serious problem in Europe where is an increasing trend in sensitization of people (Bilińska et al., 2017). This pollen is known for its high potential to cause type I allergic reactions in late summer and early autumn (Chen $e t$ al., 2018). Recent analyses reveal that the ongoing increase in temperature extremes might be contributing to extended seasonal duration and increased pollen load for many aero allergenic pollen taxa in the northern hemisphere (Ziska et al., 2019).

The Ambrosia genus has only one species, Ambrosia artemisiffolia, in the Timisoara region. During the last two decades, an accelerated spread has been observed (Ianovici and Sîrbu, 2007; Ianovici, 2009). In this study, Ambrosia pollen was selected due to its high allergenicity in a four-score scale found in the Romanian pollen index. Allergenicity of Ambrosia is the highest indicated by score four (Ianovici, 2007). Accordingly, studying influences of current and past weather conditions on pollen concentrations has of major importance. The aim of this study is to investigate Ambrosia pollen presence in western Romania, and to analyze seasonal pollen index, pollen season length, main pollen season, peak days due to the possible relationship between some meteorological parameters and its pollen concentrations.

\section{Materials and Methods}

\section{Description of the study site}

Timişoara is situated in the western region of Romania $\left(45^{\circ} 45^{\prime} \mathrm{N}, 21^{\circ} 13^{\prime} \mathrm{E}\right)$, at 88 meters above sea level. The climate is temperate continental moderate. The lowest air temperature values are recorded in January and February, with while the maximum ones are reached in July and August. Rainfall is concentrated mainly in the spring and autumn months. The highest relative humidity values were recorded at the beginning of the year, with minimum values being reached in the summer months.

Over the last decades, climatic changes in the region show increasing warm-related temperature extremes (Birsan et al., 2019), more frequent of rain showers (Busuioc et al., 2016; Manea et al., 2016), decreasing snow depth and wind speed (Birsan et al., 2013, 2020) - influencing the human health (Dobrinescu et al., 2015), terrestrial ecosystems (Mihai et al., 2018a,b) or hydrological regime (Birsan, 2015).

Mean values of the meteorological data provided by Meteo Romania (the National Meteorological Administration) are shown in Table 1.

\section{Sampling design}

The aerobiological measurement was performed using volumetric pollen trap of the Hirst design (Hirst, 1952). The air sampler is located on top of the building of the West University, approximately $20 \mathrm{~m}$ above the ground surface. Pollen grains were sampled continuously. The sampling airflow rate was $10 \mathrm{~L} / \mathrm{min}$. The transparent tape used for catching air pollen was replaced every week and cut into segments corresponding to $24 \mathrm{~h}$ periods. These segments were mounted on slides with glycerin and basic fuchsin under coverslips. Pollen grains were counted along four longitudinal transects (using a light microscope at $400 \times$ magnification) (Cariñanos et al., 2000; Ianovici, 2015). Daily pollen concentrations are expressed as particles per cubic metre of ambient air $\left(\mathrm{P} / \mathrm{m}^{3}\right)$. Because of some irrelevant circumstances, the monitoring was interrupted in 2005.

\section{Qualitative analysis}

The Seasonal Pollen Index (SPI), the sum of the daily pollen concentrations in a given season, is expressed as the number of pollen grains (Comtois, 1998). We apply the cumulative sum method to calculate the main pollen season (MPS). The start of the season was defined as the date when $5 \%$ of the pollen count was 
trapped and the end of the season as the date when $95 \%$ of the pollen count was reached (Nilsson and Persson,1981).

In order to evaluate the impact on human health, several research studies report different critical threshold values of pollen concentrations that provoke the first symptoms in sensitized patients. In this study, concentrations above $20 \mathrm{P} / \mathrm{m}^{3}$ were defined as high (Makra et al., 2005; Stępalska et al., 2016).

Table 1. Meteorological conditions in Timisoara (2000-2010)

\begin{tabular}{|c|c|c|c|c|c|c|c|c|c|c|}
\hline & & $\begin{array}{c}\text { Mean air } \\
\text { temperature } \\
\left({ }^{\circ} \mathrm{C}\right)\end{array}$ & $\begin{array}{l}\text { Maximum } \\
\text { temperature } \\
\left({ }^{\circ} \mathrm{C}\right)\end{array}$ & $\begin{array}{c}\text { Minimum } \\
\text { temperature } \\
\left({ }^{\circ} \mathrm{C}\right)\end{array}$ & $\begin{array}{c}\text { Daily } \\
\text { precipitati } \\
\text { on }(\mathrm{mm})\end{array}$ & $\begin{array}{l}\text { Relative } \\
\text { humidity } \\
(\%)\end{array}$ & $\begin{array}{l}\text { Sunshine } \\
\text { hours (h) }\end{array}$ & $\begin{array}{c}\text { Atmospher } \\
\text { ic pressure } \\
(\mathrm{mb})\end{array}$ & $\begin{array}{c}\text { Mean wind } \\
\text { speed } \\
(\mathrm{m} / \mathrm{s})\end{array}$ & $\begin{array}{c}\text { Mean daily } \\
\text { maximum } \\
\text { wind speed } \\
(\mathrm{m} / \mathrm{s})\end{array}$ \\
\hline \multirow{4}{*}{2000} & FY & 12.45 & 19.22 & 6.95 & 0.81 & 65.98 & 6.89 & 1006.14 & 1.81 & 3.14 \\
\hline & SSD & 20.50 & 28.07 & 14.06 & 0.65 & 57.26 & 8.74 & 1003.82 & 1.92 & 3.17 \\
\hline & $\mathrm{PD}$ & 20.49 & 28.03 & 14.06 & 0.65 & 57.11 & 8.77 & 1003.89 & 1.93 & 3.18 \\
\hline & MPS & 21.01 & 29.00 & 14.26 & 0.46 & 56.12 & 8.63 & 1004.31 & 1.71 & 2.88 \\
\hline \multirow{4}{*}{2001} & FY & 11.37 & 17.23 & 6.65 & 1.88 & 73.84 & 5.95 & 1005.28 & 1.98 & 2.97 \\
\hline & SSD & 19.46 & 26.44 & 14.22 & 2.20 & 72.08 & 7.84 & 1004.09 & 1.77 & 2.75 \\
\hline & PD & 19.58 & 26.51 & 14.33 & 2.22 & 71.89 & 7.87 & 1004.00 & 1.78 & 2.76 \\
\hline & MPS & 18.96 & 25.87 & 13.77 & 3.54 & 71.36 & 7.40 & 1003.12 & 1.86 & 2.74 \\
\hline \multirow{4}{*}{2002} & FY & 12.27 & 18.22 & 7.44 & 1.56 & 69.79 & 5.96 & 1005.86 & 1.91 & 2.85 \\
\hline & SSD & 18.90 & 25.38 & 14.04 & 2.37 & 72.00 & 6.87 & 1003.12 & 1.58 & 2.45 \\
\hline & $\mathrm{PD}$ & 19.02 & 25.53 & 14.13 & 2.41 & 71.86 & 6.89 & 1003.15 & 1.58 & 2.46 \\
\hline & MPS & 18.85 & 25.41 & 14.13 & 2.36 & 71.99 & 6.44 & 1003.15 & 1.65 & 2.49 \\
\hline \multirow{4}{*}{2003} & FY & 11.05 & 17.36 & 5.83 & 1.58 & 69.31 & 6.62 & 1007.19 & 1.87 & 2.76 \\
\hline & SSD & 21.01 & 28.57 & 14.61 & 1.40 & 59.18 & 8.98 & 1005.72 & 1.76 & 2.67 \\
\hline & PD & 21.15 & 28.69 & 14.71 & 1.40 & 58.96 & 9.02 & 1005.56 & 1.77 & 2.69 \\
\hline & MPS & 20.83 & 28.43 & 14.08 & 1.48 & 53.37 & 8.75 & 1005.61 & 1.70 & 2.67 \\
\hline \multirow{4}{*}{2004} & FY & 11.12 & 16.85 & 6.50 & 1.93 & 71.61 & 5.78 & 1005.94 & 1.95 & 2.88 \\
\hline & SSD & 19.20 & 26.45 & 13.38 & 1.98 & 65.65 & 8.40 & 1005.76 & 1.81 & 2.69 \\
\hline & PD & 19.32 & 26.59 & 13.43 & 1.86 & 65.45 & 8.49 & 1005.75 & 1.80 & 2.67 \\
\hline & MPS & 19.86 & 27.85 & 13.72 & 1.74 & 65.27 & 9.51 & 1005.94 & 1.71 & 2.73 \\
\hline \multirow{4}{*}{2006} & FY & 11.18 & 17.19 & 6.49 & 1.59 & 72.72 & 5.46 & 1007.09 & 1.89 & 2.75 \\
\hline & SSD & 19.14 & 26.50 & 13.69 & 1.91 & 69.35 & 7.04 & 1004.73 & 1.73 & 2.61 \\
\hline & $\mathrm{PD}$ & 19.25 & 26.58 & 13.79 & 1.91 & 69.00 & 7.06 & 1004.65 & 1.76 & 2.65 \\
\hline & MPS & 18.44 & 25.80 & 12.95 & 1.21 & 66.97 & 7.11 & 1006.52 & 1.83 & 2.80 \\
\hline \multirow{4}{*}{2007} & FY & 12.45 & 18.58 & 7.40 & 1.78 & 68.18 & 5.66 & 1005.81 & 1.98 & 2.88 \\
\hline & SSD & 20.96 & 28.58 & 14.84 & 1.87 & 61.15 & 7.57 & 1003.66 & 2.00 & 2.95 \\
\hline & PD & 21.10 & 28.69 & 14.96 & 1.87 & 60.92 & 7.61 & 1003.54 & 2.02 & 2.98 \\
\hline & MPS & 20.51 & 27.51 & 15.42 & 1.72 & 64.89 & 6.82 & 1003.01 & 1.90 & 2.93 \\
\hline \multirow{4}{*}{2008} & FY & 12.23 & 18.53 & 7.26 & 1.61 & 69.28 & 5.55 & 1006.01 & 1.92 & 2.81 \\
\hline & SSD & 20.11 & 27.33 & 14.11 & 1.65 & 63.32 & 7.46 & 1004.02 & 1.73 & 2.52 \\
\hline & $\mathrm{PD}$ & 20.22 & 27.41 & 14.24 & 1.65 & 63.30 & 7.49 & 1004.02 & 1.74 & 2.53 \\
\hline & MPS & 21.50 & 30.06 & 14.86 & 0.92 & 58.26 & 8.39 & 1003.38 & 1.72 & 2.71 \\
\hline \multirow{4}{*}{2009} & $\mathrm{FY}$ & 12.31 & 18.45 & 7.24 & 1.71 & 73.96 & 5.50 & 1004.28 & 1.84 & 2.62 \\
\hline & SSD & 21.07 & 29.01 & 14.50 & 0.76 & 67.81 & 8.10 & 1005.79 & 1.63 & 2.34 \\
\hline & $\mathrm{PD}$ & 21.13 & 29.10 & 14.55 & 0.76 & 67.73 & 8.14 & 1005.77 & 1.63 & 2.34 \\
\hline & MPS & 21.64 & 29.67 & 15.10 & 0.33 & 63.54 & 8.39 & 1006.47 & 1.64 & 2.31 \\
\hline \multirow{4}{*}{2010} & FY & 11.66 & 17.37 & 7.13 & 2.17 & 79.99 & 4.88 & 1002.99 & 1.92 & 2.72 \\
\hline & SSD & 21.00 & 27.89 & 15.58 & 1.69 & 74.40 & 7.19 & 1003.69 & 1.75 & 2.47 \\
\hline & PD & 20.97 & 27.83 & 15.54 & 1.57 & 74.47 & 7.18 & 1003.80 & 1.75 & 2.45 \\
\hline & MPS & 20.33 & 27.25 & 14.77 & 2.47 & 72.63 & 7.32 & 1004.37 & 1.79 & 2.60 \\
\hline
\end{tabular}

\section{Statistical procedures}

To test assumptions of ANOVA data were tested for normality of variances with Shapiro-Wilk's test. The similarities between pollen season parameters were determined on the basis of the results of cluster analysis. Data clustering was performed using the Ward's method and the k-means method. In this way a pollen season is classified into a particular cluster by minimizing within the cluster variance and maximizing between the cluster variances (Piotrowska and Kubik-Komar, 2012). Pollen seasons were grouped in terms of the season 
parameters (seasonal pollen index - SPI; pollen season length; main pollen season - MPS; number of days with pollen concentrations over $20 \mathrm{P} / \mathrm{m}^{3}$; concentration in the peak day of the year).

The statistical techniques usually employed to study pollen concentrations trends are correlation and regression analyses (García-Mozo et al., 2014; Ianovici, 2017). Simple linear regression of SPI against to year was carried out for Ambrosia pollen. After that, the correlation coefficients between daily air pollen concentrations and daily meteorological variables were analysed. The Pearson's parametric test was chosen because daily pollen concentrations are normally distributed. Pearson's correlation test was performed in order to identify the meteorological parameters that are likely to influence the annual dynamic of the Ambrosia airborne pollen. The significance was calculated for $\mathrm{P}<0.05$. We analysed the effect of the main meteorological variables on pollen concentrations taking the pollen season length as a whole, over a full year (FY). The meteorological variables considered in this study were: mean, maximum and minimum air temperature $\left({ }^{\circ} \mathrm{C}\right)$; relative humidity (\%); atmospheric pressure $(\mathrm{mb})$; number of sunshine hours $(\mathrm{h})$; mean daily precipitation $(\mathrm{mm})$, maximum daily wind speed $(\mathrm{m} / \mathrm{s})$; mean wind speed $(\mathrm{m} / \mathrm{s})$. In the next step, the daily values of the current (meteorological parameters from the same sampling day -SSD) and preceding (meteorological parameters from the previous day - PD) weather variables influencing the pollen season length were used in this study. Finally, the values included in the main pollen season (MPS) were used for the statistical analysis.

The accumulated heat is introduced in some models that forecast MPS particularities (Zhang et al., 2015; Ritenberga et al., 2018). The impact of cumulative temperature (average, maximum and minimum temperature) and cumulative sunshine hours calculated from 1 January until the date of the beginning of the pollen season was examined. This method did not give positive results in our case.

Complementary with the Pearson's correlation test, the multiple regression analysis was used in order to determine how much of total variance in these pollen concentrations can be explained by meteorological variables.

The all data were processed with Microsoft Excel for Windows, PAST and SPSS software package.

\section{Results}

In the first part of this section, there will be presented the results of aerobiological observations based on airborne pollen concentrations, and the second part shows the meteorological aspects of this study.

The aerobiological parameters in each year (excluding 2005 because of incomplete sampling) are given in Table 2.

Table 2. Aerobiological parameters of Ambrosia pollen concentrations in the particular clusters

\begin{tabular}{|c|c|c|c|c|c|c|c|c|}
\hline Cluster & Year & $\begin{array}{l}\text { SPI (Seasonal } \\
\text { Pollen Index) }\end{array}$ & $\begin{array}{l}\text { Number of days with } \\
\text { pollen concentrations } \\
\text { higher than } 20 \mathrm{P} / \mathrm{m}^{3}\end{array}$ & \multicolumn{2}{|c|}{$\begin{array}{l}\text { Pollen season } \\
\text { length }\end{array}$} & \multicolumn{2}{|c|}{$\begin{array}{l}\text { MPS- days } \\
\text { (90\% method) }\end{array}$} & $\begin{array}{c}\text { Seasonal } \\
\text { maximum daily } \\
\text { count } \\
\text { (concentration }\end{array}$ \\
\hline \multirow{6}{*}{ A } & 2000 & 2848 & 42 & 116 & $20.06-13.09$ & 41 & $10.08-19.09$ & 170 \\
\hline & 2001 & 2329 & 40 & 96 & $11.07-14.10$ & 47 & $06.08-21.09$ & 95 \\
\hline & 2002 & 4473 & 59 & 98 & $08.07-01.10$ & 69 & $25.07-13.10$ & 234 \\
\hline & 2003 & 3603 & 48 & 89 & $02.07-28.09$ & 43 & $06.08-17.09$ & 319 \\
\hline & 2004 & 3131 & 38 & 110 & $24.06-11.10$ & 44 & $03.08-15.09$ & 220 \\
\hline & 2007 & 3367 & 36 & 84 & $03.07-24.09$ & 28 & $15.08-11.09$ & 230 \\
\hline \multirow{4}{*}{ B } & 2006 & 6899 & 45 & 89 & $18.07-14.10$ & 30 & $19.08-17.09$ & 468 \\
\hline & 2008 & 5217 & 51 & 109 & $20.06-06.10$ & 38 & $08.08-14.09$ & 320 \\
\hline & 2009 & 5591 & 54 & 100 & $04.07-11.10$ & 39 & 09.08-16.09 & 292 \\
\hline & 2010 & 5942 & 47 & 92 & $27.07-26.09$ & 35 & $10.08-26.09$ & 413 \\
\hline
\end{tabular}


In the years examined in Timisoara, the number of days when the threshold value was exceeded was high. The highest value was seen for 59 days in 2002. The concentration in a peak day showed great variation between years and varied $95-468 \mathrm{P} / \mathrm{m}^{3}$. The peak daily concentration was noted on September 6, 2006. The seasonal pollen index of Ambrosia pollen ranged 2329-6899 pollen grains. The mean seasonal pollen index obtained during the studied period (2000-2010) was $4340 \mathrm{P} / \mathrm{m}^{3}$. The lowest seasonal pollen index was recorded in 2000 and the highest annual sum in 2006. The pollen season length lasted in Timisoara from 116 days in 2000 to 84 days in 2007. Among the years studied, 2007 was characterized by a short main pollen season. Based on the available data set, it was established that the longest main pollen season was in 2002. Start dates were found in the first half of August (9 years) or in the second half of August (1 year - 2006). Usually small amounts of airborne pollen are present at the start of the seasons (at the end of June and July) (Figure 1).

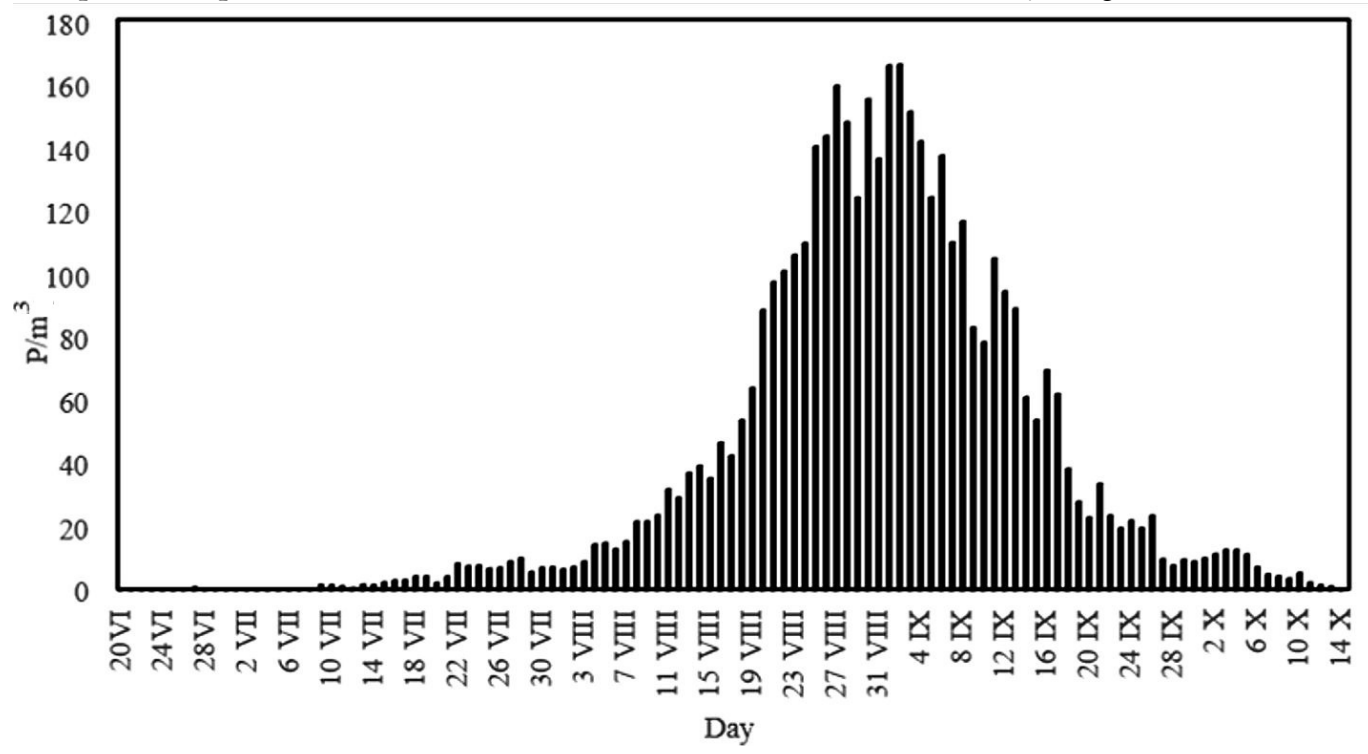

Figure 1. Mean daily Ambrosia pollen concentrations over the pollen season (20 June - 14 October) in Timisoara from 2000 to 2010

The one-way ANOVA test revealed that the Ambrosia pollen concentrations do differ among years $(\mathrm{F}=4.148 ; \mathrm{p}>0.00002447)$. More significantly statistically differences are in the case of taking into account only the days with the presence of pollen in the ambient air ( $F=7.049 ; \mathrm{p}>0.0000000006382)$.

The similarity between atmospheric pollen concentrations was determined using cluster analysis. The results are presented in the form of dendrogram (Figure 2). In terms of pollen season parameters, two clusters were distinguished: 2000, 2001, 2002, 2003, 2004 and 2007 (A); 2006, 2008, 2009, and 2010 (B). The 2006 season was characterized by a late onset, a short duration, and at the same time, very abundant pollen emission. Moreover, apart from the year 2006, a high SPI were observed in 2008, 2009 and 2010.Temporal linear trend show the Ambrosia pollen concentrations increases at a steady rate during the 10 years of study (Figure 3).

In the second part, the meteorological aspects will be presented. Assessment of the influences of meteorological parameters on pollen concentrations in the atmosphere, based on systemized results, is presented in Table 3. 


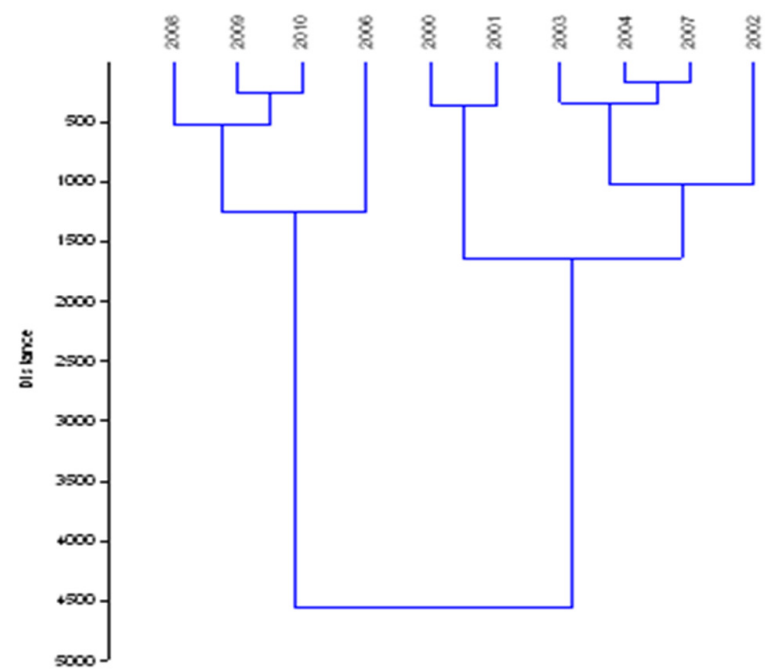

Figure 2. Groups of Ambrosia pollen seasons identified on the basis of the seasonal parameters in Timisoara in the period 2000-2010

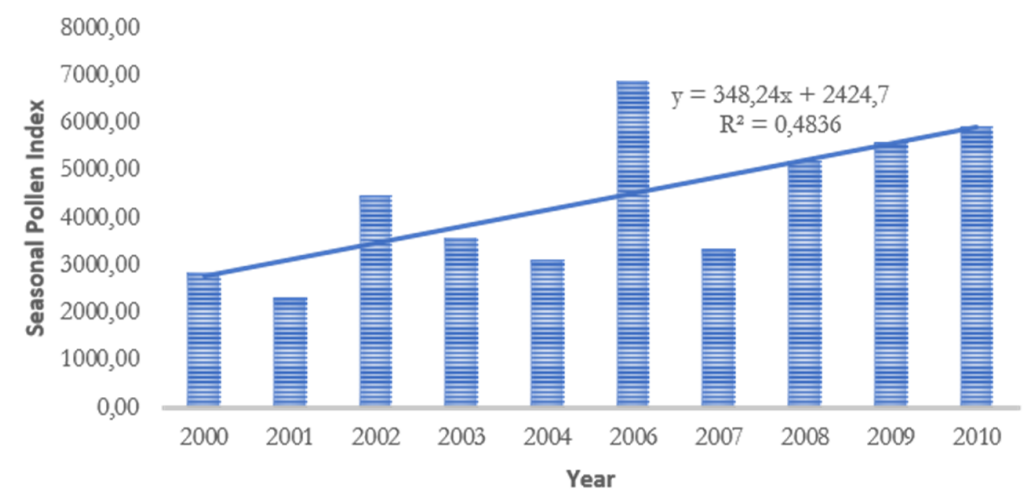

Figure 3. Linear regression of the Seasonal Pollen Index

The correlations between the Ambrosia pollen and meteorological factors over a full year (FY)

The correlation coefficients were not statistically significant in the case of all the meteorological factors in question. All the pollen concentrations increase when the temperatures (mean, maximum, minimum) increases. The strongest correlation was seen for 2001 and 2009. Pearson's correlation analysis also revealed the negative and significant influence of relative air humidity (with average annual values over 65\%) on airborne pollen. The total daily hours of sunshine had obtained positive and significant correlations with pollen concentrations in all years (except 2000). The correlation coefficients were lower for daily average wind speed, daily maximum wind speed and atmospheric pressure. In relation to daily average wind speed, the correlation was significant and negative in the case of 2002, 2003, 2008 and 2009. Weak negative correlations were observed in the case of quantities of precipitations. The atmospheric pressure influences are mixed between 2000-2010. 
Table 3. Pearson's correlation coefficients between Ambrosia pollen concentrations and main meteorological parameters

\begin{tabular}{|c|c|c|c|c|c|c|c|c|c|c|}
\hline \multicolumn{2}{|c|}{ Pearson correlation } & \multirow{2}{*}{$\begin{array}{c}\begin{array}{c}\text { Mean daily } \\
\text { average } \\
\text { temperature } \\
\left({ }^{\circ} \mathrm{C}\right)\end{array} \\
\mathbf{. 2 9 3}^{\text {** }}\end{array}$} & \multirow{2}{*}{$\begin{array}{c}\begin{array}{c}\text { Maximum } \\
\text { temperature } \\
\left({ }^{\circ} \mathrm{C}\right)\end{array} \\
. \mathbf{2 9 0}\end{array}$} & \multirow{2}{*}{$\begin{array}{c}\begin{array}{c}\text { Minimum } \\
\text { temperature } \\
\left({ }^{\circ} \mathrm{C}\right)\end{array} \\
\mathbf{3 0 3}^{* *}\end{array}$} & \multirow{2}{*}{$\begin{array}{c}\text { Quantities of } \\
\text { precipitations } \\
\left(\mathrm{L} / \mathrm{m}^{2}\right)\end{array}$} & \multirow{2}{*}{$\begin{array}{c}\begin{array}{c}\text { Daily average } \\
\text { relative } \\
\text { humidity (\%) }\end{array} \\
\mathbf{. 1 9 1}^{* * *}\end{array}$} & \multirow{2}{*}{$\begin{array}{r}\text { Sunshine } \\
\text { hours (h) }\end{array}$} & \multirow{2}{*}{$\begin{array}{c}\begin{array}{c}\text { Atmospheric } \\
\text { pressure } \\
\text { (milibars) }\end{array} \\
\mathbf{. 1 2 0}^{*}\end{array}$} & \multirow{2}{*}{$\begin{array}{c}\begin{array}{c}\text { Daily } \\
\text { average } \\
\text { wind } \\
\text { speed } \\
(\mathrm{m} / \mathrm{s})\end{array} \\
-.007\end{array}$} & \multirow{2}{*}{$\begin{array}{c}\begin{array}{c}\text { Daily max } \\
\text { wind } \\
\text { speed } \\
(\mathrm{m} / \mathrm{s})\end{array} \\
-.023\end{array}$} \\
\hline \multirow{4}{*}{2000} & FY & & & & & & & & & \\
\hline & SD & -.044 & -.009 & -.017 & .001 & .088 & -.181 & -.031 & -.080 & -.071 \\
\hline & PD & .010 & .050 & .024 & -.059 & .084 & -.141 & -.022 & -.091 & -.110 \\
\hline & MPS & .095 & .138 & .043 & -.086 & -.085 & -.086 & .001 & -.160 & -.137 \\
\hline \multirow{4}{*}{2001} & FY & $.339^{* * s}$ & $.340^{* * *}$ & $.348^{* * *}$ & .061 & -.098 & $.158^{* *}$ & $-.108^{*}$ & -.092 & -.091 \\
\hline & SD & -.031 & .007 & -.065 & .073 & -.115 & .002 & $-.219^{*}$ & -.025 & -.097 \\
\hline & PD & -.030 & .010 & -.077 & .006 & -.153 & .013 & -.136 & $\begin{array}{l}-.035 \\
\end{array}$ & -.098 \\
\hline & MPS & .129 & .171 & .083 & -.102 & -.196 & .155 & -.164 & -.226 & -.203 \\
\hline \multirow{4}{*}{2002} & FY & $.284^{* * *}$ & $.299^{* * *}$ & $.286^{* * *}$ & -.019 & -.026 & $.162^{* *}$ & -.039 & $-.128^{*}$ & $-.144^{* * *}$ \\
\hline & SD & .003 & .133 & -.105 & -.176 & $-.278^{* * *}$ & $.233^{*}$ & $.395^{* *}$ & $\begin{array}{r}-.011 \\
\end{array}$ & -.122 \\
\hline & PD & $\begin{array}{l}.009 \\
\end{array}$ & .112 & -.101 & -.132 & $-.268^{* * *}$ & $.203^{*}$ & $.352^{* * *}$ & -.059 & -.153 \\
\hline & MPS & .175 & $.306^{*}$ & .002 & -.199 & $-.422^{* * *}$ & $.403^{s *}$ & $.388^{* * *}$ & -.057 & -.199 \\
\hline \multirow{4}{*}{2003} & FY & $.278^{* * *}$ & .301** & $.247^{* * *}$ & -.077 & $-.302^{* *}$ & $.195^{* *}$ & -.070 & $-.143^{* * i}$ & -.092 \\
\hline & SD & $\begin{array}{l}-.060 \\
\end{array}$ & .084 & $-.233^{*}$ & -.130 & $-.274^{* * *}$ & .110 & -.034 & $-.286^{* * ;}$ & -.191 \\
\hline & PD & -.095 & -.014 & $-.226^{*}$ & -.024 & $-.269^{*}$ & .045 & .005 & $-.253^{*}$ & -.181 \\
\hline & MPS & -.001 & .157 & -.171 & -.173 & -.107 & .210 & -.199 & $-.323^{*}$ & -.221 \\
\hline \multirow{4}{*}{2004} & FY & $.260^{* 49}$ & $.282^{* * *}$ & $.239^{* * *}$ & -.073 & $-.212^{* * *}$ & $.184^{* *}$ & $.136^{* * 4}$ & $\begin{array}{l}-.054 \\
\end{array}$ & .005 \\
\hline & SD & -.154 & -.063 & $-.236^{*}$ & -.139 & -.110 & -.001 & $.436^{* *}$ & -.015 & .144 \\
\hline & PD & -.142 & -.046 & $-.229^{*}$ & -.143 & $\begin{array}{l}.051 \\
\end{array}$ & -.004 & $.418^{* *}$ & -.042 & .104 \\
\hline & MPS & $-.574^{\text {s* }}$ & $-.530^{6 *}$ & $-.594^{* *}$ & -.195 & $-.438^{* * *}$ & -.263 & $.739^{* 4}$ & .157 & .257 \\
\hline \multirow{4}{*}{2006} & FY & $.219^{* * *}$ & $.229^{* * *}$ & $.221^{* *}$ & .025 & -.100 & $.121^{*}$ & -.034 & -.033 & .003 \\
\hline & SD & $-.258^{*}$ & $-.230^{*}$ & $-.262^{*}$ & .002 & .005 & .004 & .199 & .063 & .105 \\
\hline & PD & $-.245^{*}$ & $-.240^{*}$ & $-.249^{*}$ & -.018 & .035 & -.043 & .199 & .038 & .105 \\
\hline & MPS & $-.508^{* * i}$ & $-.369^{*}$ & $-.464^{* *}$ & .250 & $.395^{*}$ & .033 & .116 & -.122 & -.036 \\
\hline \multirow{4}{*}{2007} & FY & $.301^{* k}$ & $.288^{* * *}$ &. $\mathbf{3 3 5}^{* * *}$ & $\begin{array}{l}-.041 \\
\end{array}$ & $-.136{ }^{* *}$ & $.129^{*}$ & -.071 & .020 & .071 \\
\hline & SD & .048 & .016 & .155 & -.093 & .040 & -.029 & .048 & .036 & .151 \\
\hline & PD & .091 & .061 & .202 & $\begin{array}{l}.098 \\
\end{array}$ & .036 & .035 & .068 & -.140 & $\begin{array}{l}.009 \\
\end{array}$ \\
\hline & MPS & $.428^{*}$ & $.409^{*}$ & $.434^{*}$ & -.195 & $-.506^{* * 4}$ & .285 & .204 & $.425^{*}$ & $.533^{* * 4}$ \\
\hline \multirow{4}{*}{2008} & FY & $.309^{* *}$ & $.319^{* * *}$ & $.303^{* * *}$ & -.006 & $-.225^{* * 4}$ & $.170^{* * *}$ & -.053 & $-.119^{*}$ & -.082 \\
\hline & SD & .008 & .082 & -.010 & -.015 & -.113 & .019 & .116 & -.112 & -.015 \\
\hline & PD & -.002 & .103 & -.080 & -.068 & -.144 & .068 & .150 & -.147 & -.019 \\
\hline & MPS & -.259 & -.242 & -.193 & .208 & .218 & -.154 & $.520^{* * 4}$ & -.270 & -.228 \\
\hline \multirow{4}{*}{2009} & FY & $.351^{* *}$ & $.368^{* * *}$ &. $\mathbf{3 4 3}^{* *}$ & -.084 & $-.246^{* * *}$ & $.255^{3 *+}$ & $.105^{*}$ & $-.105^{*}$ & -.099 \\
\hline & SD & .121 & $.215^{*}$ & .135 & -.079 & $-.350^{* * *}$ & .093 & .118 & -.041 & -.048 \\
\hline & PD & .130 & $.220^{*}$ & .090 & -.079 & $-.400^{* * *}$ & .168 & $.224^{*}$ & -.082 & -.099 \\
\hline & MPS & .233 & $.412^{* * 4}$ & .148 & .289 & $-.358^{*}$ & .186 & -.131 & -.080 & -.014 \\
\hline \multirow{4}{*}{2010} & FY & $.266^{* * a}$ & $.272^{* * *}$ & $.249^{* * *}$ & -.031 & $-.216^{* * *}$ & $.190^{* * *}$ & .048 & -.065 & -.047 \\
\hline & SD & $-.361^{* * *}$ & $-.269^{* *}$ & $-.449^{* * *}$ & .004 & -.137 & $\begin{array}{l}.007 \\
\end{array}$ & .068 & -.010 & .048 \\
\hline & PD & $-.311^{s \pi}$ & $-.260^{n}$ & $-.352^{2 *}$ & .069 & $-.210^{*}$ & .017 & .080 & .037 & .068 \\
\hline & MPS & $-.455^{3 n}$ & -.294 & $-.585^{\text {sth }}$ & -.187 & -.106 & -.037 & -.107 & -.083 & -.079 \\
\hline
\end{tabular}

The correlations between the Ambrosia pollen and meteorological factors only from the same sampling day $(S S D)$

Secondly, we took into consideration all days when the pollen grains were present in the air. Overall, the correlations with temperature were not significant when data is restricted to the period of pollen grains being released. However, significant negative correlations were observed in the case of temperatures in 2006 and 2010. The results have shown that the level of Ambrosia pollen in 2002 was significant positive affected by sunshine hours on the same day. In relation to daily average wind speed, the correlation was significant and negative only in the case of 2003 . For three years $(2002,2003,2009)$ was negative correlation detected between pollen concentrations and relative air humidity. The effect of atmospheric pressure on airborne pollen concentrations can be positive (2002 and 2004) and negative (2001).

The correlations between the Ambrosia pollen and meteorological factors from the previous day (PD)

We have chosen the weather variables on the day before to the appearance of airborne pollen to see if it confirms the statistical data on the SSD. Weak positive correlation was observed in the case of maximum 
temperature in a day earlier for 2009. In some years $(2003,2004,2006,2010)$ Ambrosia pollen presented a significant negative correlation with minimum temperature on the previous day. Pollen concentrations showed a negative and significant correlations with daily average relative humidity on the day before sampling (2002, 2003, 2009 and 2010). The relationship with the sunshine hours was not so close. The effect of atmospheric pressure on airborne pollen concentrations was positive (2002, 2004 and 2009).

The correlations between the Ambrosia pollen and meteorological factors from the main pollen season (MPS)

Over a full year, the pollen season length exhibits a strong temporal course, with a winter, spring and late autumn periods free of pollen. The MPS is applied to reduce the coefficient of variability of pollen concentration data. Overall, the negative correlations with relative humidity were significant when data is restricted to the MPS. The same meteorological variable (mean temperature, maximum temperature, minimum temperature or wind speed) may have different influences in different years.

\section{Ambrosia airborne pollen dependence on the weather in multiple linear regression analysis}

Table 4 shows the results of multiple linear regressions. Only the values of the statistically significant coefficients were selected. The most important variables statistically significantly different to 0 were not the same for each year. Unstandardized coefficients B indicate how much the Ambrosia pollen concentration (dependent variable) varies with an independent variable when all other independent variables are held constant. Unstandardized coefficients B for the same variable were negative in some cases and positive in others (sunshine hours, atmospheric pressure, wind speed). The most surprising aspects are caught in the case of temperature. Lowering the temperature from very high values and raising the temperature from lower values are associated with increasing pollen concentrations. For Ambrosia pollen concentrations, meteorological parameters explained $7.5 \%$ of the total variance in 2006 and $18.3 \%$ in 2009 . The values of the $\mathrm{R}^{2}$ obtained over a full year (FY) were quite inferior to those of SSD, PD or MPS. The proportion of variance explained during MPS is high (ranged from $13.70 \%$ until $68.40 \%$ ).

\section{Discussion}

This study highlights the difficulty in interpretations relating the associations between Ambrosia pollen concentrations and meteorological variables. Airborne pollen concentrations over the full year (FY) were found to be positively correlated with several climatic factors (mean temperature, maximum temperature, minimum temperature) and negatively correlated with others (quantities of precipitations, daily average wind speed). In this way, we included the data from all phenological phases of plants. The results of Pearson's correlation test showed that the atmospheric pollen release is occasionally affected by the daily maximum wind speed. In the present study, we found a positive correlation between Ambrosia pollen concentrations and sunshine hours. Because photoperiod is defined as the period of sunshine hours necessary for flowering, it can be considered that sunshine hours are correlated directly with the specific photoperiod of this plant (Vázquez et al., 2003). The level of daily pollen concentration is also affected by the prior meteorological conditions (Matyasovszky et al., 2015; Wozniak and Steiner, 2017). When data is restricted to the period of pollen grains being released, temperature (with all its components) was the most correlated with the pollen concentrations. Relative humidity and sunshine hours also showed to have some correlations on the pollen emission. Nevertheless, the results for each year were different depending on the analyzed period (FY, SSD, PD and MPS). 
Ianovici N and Birsan M-V (2020). Not Bot Horti Agrobo 48(2)752-769

Table 4. Multiple linear regression variable results

\begin{tabular}{|c|c|c|c|c|c|c|c|c|}
\hline \multicolumn{2}{|c|}{ Year } & $\begin{array}{c}\text { Multiple } \\
\text { correlation }\end{array}$ & $\begin{array}{l}\text { Coefficient of } \\
\text { determination }\end{array}$ & ANOVA - & $\begin{array}{l}\text { Proportion of } \\
\text { variance }\end{array}$ & Explanatory & $\begin{array}{c}\text { Unstandardized } \\
\text { Coefficients B }\end{array}$ & $P$-value \\
\hline \multirow{4}{*}{2000} & FY & 0.359 & .128 & 5.821 & $12.86 \%$ & sunshine hours & -1.364 & .00205 \\
\hline & SD & 0.29 & .084 & 1.084 & $8.40 \%$ & $\begin{array}{l}\text { sunshine hours } \\
\text { sul }\end{array}$ & -2.787 & .0391 \\
\hline & PD & 0.328 & .108 & 1.422 & $10.8 \%$ & sunshine hours & -2.917 & .02837 \\
\hline & MPS & 0.37 & .137 & 1.866 & $13.70 \%$ & sunshine hours & -4.012 & .0034 \\
\hline \multirow{6}{*}{2001} & \multirow{2}{*}{ FY } & \multirow{2}{*}{0.393} & \multirow{2}{*}{.155} & \multirow{2}{*}{7.241} & \multirow{2}{*}{$15.50 \%$} & maximum temperature & 1.107 & .0365 \\
\hline & & & & & & minimum temperature & 1.361 & .04049 \\
\hline & \multirow[t]{2}{*}{ SD } & \multirow[t]{2}{*}{0.453} & \multirow[t]{2}{*}{.205} & 2.470 & $20.50 \%$ & $\begin{array}{c}\text { daily average relative } \\
\text { humidity }\end{array}$ & -1.375 & .0094 \\
\hline & & & & & & atmospheric pressure & -1.885 & .0089 \\
\hline & PD & 0.429 & .184 & 2.154 & $18.40 \%$ & $\begin{array}{c}\text { daily average relative } \\
\text { humidity }\end{array}$ & -1.667 & .0020 \\
\hline & MPS & 0.498 & .248 & 1.356 & $24.80 \%$ & atmospheric pressure & -2.759 & .0324 \\
\hline & & & & & & $\begin{array}{c}\text { mean daily average } \\
\text { temperature }\end{array}$ & -5.598 & .0066 \\
\hline & & & & & & maximum temperature & 4.312 & .0001 \\
\hline & FY & 0.421 & .177 & 8.510 & $177 \%$ & minimum temperature & 2.997 & .0171 \\
\hline & & & & & 17.17 & $\begin{array}{l}\text { daily average relative } \\
\text { humidity }\end{array}$ & .378 & .0484 \\
\hline & & & & & & atmospheric pressure & .728 & .0238 \\
\hline & & & & & & daily max. wind speed & -5.158 & .0354 \\
\hline & & & & & & maximum temperature & 11.968 & .0009 \\
\hline 2003 & SD & 0.586 & 343 & 5.12 & $3430 \%$ & atmospheric pressure & 3.982 & .0013 \\
\hline 2002 & ע & 0.500 & . & 3.112 & $34.50 \%$ & daily average wind speed & 34.066 & .0028 \\
\hline & & & & & & daily max. wind speed & -19.838 & .0046 \\
\hline & & & & & & $\begin{array}{c}\text { mean daily average } \\
\text { temperature }\end{array}$ & -14.757 & .046 \\
\hline & & & & & & maximum temperature & 10.701 & .0040 \\
\hline & PD & 0.334 & .200 & 3.900 & $20.00 \%$ & atmospheric pressure & 3.319 & .0085 \\
\hline & & & & & & daily average wind speed & 23.933 & .0416 \\
\hline & & & & & & daily max. wind speed & -17.291 & .0178 \\
\hline & & & & & & maximum temperature & 10.367 & .0317 \\
\hline & MPS & 0.617 & .381 & 4.031 & $38.10 \%$ & atmospheric pressure & 3.503 & .0320 \\
\hline & & & & & $30.10 \%$ & daily average wind speed & 32.500 & .0291 \\
\hline & & & & & & daily max. wind speed & -25.012 & .0104 \\
\hline & & & & & & maximum temperature & 2.205 & .04994 \\
\hline & FY & 0.418 & .174 & 8.335 & $17.40 \%$ & $\begin{array}{c}\text { daily average relative } \\
\text { humidity }\end{array}$ & -.841 & .0001 \\
\hline & & & & & & sunshine hours & -1.408 & .0287 \\
\hline & & & & & & daily average wind speed & -12.396 & .0044 \\
\hline & SD & & & & & $\begin{array}{l}\text { daily average relative } \\
\text { humidity }\end{array}$ & -2.368 & .0012 \\
\hline 2003 & SD & 0.603 & .364 & 5.016 & $36.40 \%$ & atmospheric pressure & -3.349 & .0211 \\
\hline & & & & & & daily average wind speed & -46.188 & .0069 \\
\hline & PD & 0.566 & .320 & 4.140 & $32 \%$ & $\begin{array}{c}\text { daily average relative } \\
\text { humidity }\end{array}$ & -3.013 & .00006 \\
\hline & & & & & & daily average wind speed & -42.387 & .01562 \\
\hline & MPS & 0.696 & .485 & 3.453 & $49.50 \%$ & sunshine hours & 11.753 & .0174 \\
\hline & & & & & & atmospheric pressure & -10.782 & .0006 \\
\hline & FY & 0377 & 142 & 6.552 & $1420 \%$ & maximum temperature & 2.500 & .0051 \\
\hline & $r 1$ & $0.5 \% 1$ & .142 & 0.332 & $14.20 \%$ & atmospheric pressure & .829 & .0002 \\
\hline & SD & 0.555 & 308 & 4945 & $30.80 \%$ & atmospheric pressure & 3.684 & .00015 \\
\hline 2004 & ע & נקנ.0 & .500 & 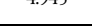 & $50.00 \%$ & daily max. wind speed & 19.141 & .0029 \\
\hline & PD & 0.514 & 264 & 3981 & $2640 \%$ & atmospheric pressure & 3.691 & .00022 \\
\hline & 10 & 0.314 & .207 & $3 . \% 01$ & 20.4070 & daily max. wind speed & 17.057 & .00962 \\
\hline & MPS & 0.827 & .684 & 8.166 & $68.40 \%$ & atmospheric pressure & 5.435 & .0030 \\
\hline & FY & 0.274 & .075 & 3.207 & $7.50 \%$ & $\begin{array}{l}\text { mean daily average } \\
\text { temperature }\end{array}$ & -8.800 & .0477 \\
\hline 200 & & & & & & maximum temperature & 5.171 & .0207 \\
\hline 2006 & SD & 0.402 & .161 & 1.689 & $16.10 \%$ & - & - & - \\
\hline & PD & 0.386 & .149 & 1.533 & $14.90 \%$ & - & - & - \\
\hline & MPS & 0.666 & .443 & 1.770 & $44.30 \%$ & - & - & - \\
\hline & & & & & & $\begin{array}{c}\text { mean daily average } \\
\text { temperature }\end{array}$ & -5.638 & .01074 \\
\hline & FY & 0.413 & 171 & & $17.10 \%$ & maximum temperature & 2.313 & .04719 \\
\hline & FY & 0.413 & $.1 / 1$ & & $17.10 \%$ & minimum temperature & 5.268 & .00009 \\
\hline & & & & & & daily average wind speed & -9.432 & .02913 \\
\hline 2007 & & & & & & daily max. wind speed & 8.039 & .00465 \\
\hline & SD & 0.445 & .198 & 2.026 & $19.80 \%$ & minimum temperature & 13.660 & .01641 \\
\hline & PD & 0.532 & 283 & 3251 & $28.30 \%$ & minimum temperature & 18.340 & .00086 \\
\hline & 10 & 0.332 & 203 & 3.231 & $20.50 \%$ & daily average wind speed & -36.470 & .03303 \\
\hline & MPS & 0.759 & .575 & 2.710 & $57.50 \%$ & - & - & - \\
\hline & & & & & & $\begin{array}{c}\text { mean daily average } \\
\text { temperature }\end{array}$ & -5.760 & .03778 \\
\hline & & & & & & maximum temperature & 3.662 & .01090 \\
\hline 2008 & FY & 0.395 & 156 & 7324 & $15.60 \%$ & minimum temperature & 3.812 & .03468 \\
\hline 2000 & $1+1$ & ד & 1.10 & 1.021 & (1).00 & $\begin{array}{l}\text { daily average relative } \\
\text { humidity }\end{array}$ & -1.115 & .00149 \\
\hline & & & & & & sunshine hours & -2.543 & .02333 \\
\hline & & & & & & daily average wind speed & -13.018 & .02982 \\
\hline
\end{tabular}


Ianovici N and Birsan M-V (2020). Not Bot Horti Agrobo 48(2)752-769

\begin{tabular}{|c|c|c|c|c|c|c|c|c|}
\hline & \multirow{3}{*}{ SD } & \multirow{3}{*}{0.419} & \multirow{3}{*}{.176} & \multirow{3}{*}{2.344} & \multirow{3}{*}{$17.60 \%$} & $\begin{array}{c}\text { mean daily average } \\
\text { temperature }\end{array}$ & -21.768 & .02990 \\
\hline & & & & & & maximum temperature & 11.678 & .00687 \\
\hline & & & & & & $\begin{array}{c}\text { daily average relative } \\
\text { humidity }\end{array}$ & -3.237 & .00809 \\
\hline & \multirow{3}{*}{ PD } & \multirow{3}{*}{0.504} & \multirow{3}{*}{.254} & \multirow{3}{*}{3.748} & \multirow{3}{*}{$25.40 \%$} & $\begin{array}{c}\text { mean daily average } \\
\text { temperature }\end{array}$ & -21.828 & .02199 \\
\hline & & & & & & maximum temperature & 14.277 & .00060 \\
\hline & & & & & & $\begin{array}{c}\text { daily average relative } \\
\text { humidity }\end{array}$ & -3.324 & .0045 \\
\hline & MPS & 0.715 & .511 & 3.253 & $51.10 \%$ & atmospheric pressure & 15.118 & .0007 \\
\hline \multirow{16}{*}{2009} & \multirow{4}{*}{ FY } & \multirow{4}{*}{0.428} & \multirow{4}{*}{.183} & \multirow{4}{*}{8.836} & \multirow{4}{*}{$18.30 \%$} & $\begin{array}{c}\text { mean daily average } \\
\text { temperature }\end{array}$ & -8.314 & .0017 \\
\hline & & & & & & maximum temperature & 4.323 & .0023 \\
\hline & & & & & & minimum temperature & 5.523 & .0015 \\
\hline & & & & & & $\begin{array}{c}\text { daily average relative } \\
\text { humidity }\end{array}$ & -.601 & .0175 \\
\hline & \multirow{4}{*}{ SD } & \multirow{4}{*}{0.624} & \multirow{4}{*}{.389} & \multirow{4}{*}{6.369} & \multirow{4}{*}{$38.90 \%$} & $\begin{array}{c}\text { mean daily average } \\
\text { temperature }\end{array}$ & -45.866 & .000001 \\
\hline & & & & & & maximum temperature & 19.603 & .000189 \\
\hline & & & & & & minimum temperature & 30.395 & .000009 \\
\hline & & & & & & $\begin{array}{c}\text { daily average relative } \\
\text { humidity }\end{array}$ & -5.190 & .0000002 \\
\hline & \multirow{4}{*}{ PD } & \multirow{4}{*}{0.601} & \multirow{4}{*}{.361} & \multirow{4}{*}{5.654} & \multirow{4}{*}{$36.10 \%$} & $\begin{array}{c}\text { mean daily average } \\
\text { temperature }\end{array}$ & -35.520 & .0001 \\
\hline & & & & & & maximum temperature & 14.532 & .0063 \\
\hline & & & & & & minimum temperature & 25.585 & .0002 \\
\hline & & & & & & $\begin{array}{c}\text { daily average relative } \\
\text { humidity }\end{array}$ & -4.804 & .000002 \\
\hline & \multirow{4}{*}{ MPS } & \multirow{4}{*}{0.719} & \multirow{4}{*}{.517} & \multirow{4}{*}{3.453} & \multirow{4}{*}{$51.70 \%$} & $\begin{array}{c}\text { mean daily average } \\
\text { temperature }\end{array}$ & -53.085 & .0076 \\
\hline & & & & & & maximum temperature & 36.997 & .0024 \\
\hline & & & & & & $\begin{array}{c}\text { quantities of } \\
\text { precipitations }\end{array}$ & 18.906 & .0245 \\
\hline & & & & & & $\begin{array}{c}\text { daily average relative } \\
\text { humidity }\end{array}$ & -3.484 & .0415 \\
\hline & FY & 0.291 & .085 & 3.659 & $8.50 \%$ & - & - & - \\
\hline & SD & 0.59 & .348 & 4.862 & $34.80 \%$ & $\begin{array}{c}\text { daily average relative } \\
\text { humidity }\end{array}$ & -5.959 & .0013 \\
\hline 2010 & & & & & & $\begin{array}{c}\text { mean daily average } \\
\text { temperature }\end{array}$ & -34.143 & .0188 \\
\hline & $\mathrm{PD}$ & 0.615 & .378 & 5.539 & $37.80 \%$ & $\begin{array}{c}\text { daily average relative } \\
\text { humidity }\end{array}$ & -9.453 & .0000006 \\
\hline & MPS & 0.748 & .560 & 3.535 & $56 \%$ & - & - & - \\
\hline
\end{tabular}

The Ambrosia MPS exhibits a distinct pattern. Ambrosia is most commonly a short-day plant that begins flowering when days begin to shorten (Ziska et al., 2011; Lo et al., 2019). The pollen season presents similar behaviour and duration in Hungary, Serbia and Croatia, which can be explained by the biogeographical and bioclimatic conditions. Some researchers have shown the significant and positive correlations of daily pollen concentrations with daily mean temperature (Bartkova-Scevkova, 2003; Štefanić et al., 2005; Peternel et al., 2006), daily maximum temperature (Stepalska et al., 2008), daily mean wind speed (Kasprzyk, 2008), and daily maximum wind speed (Puc, 2006). They were also mentioned the significant and negative correlations with relative humidity (Kasprzyk, 2008) and rainfall (Peternel et al., 2005; Peternel et al., 2006,). Ambrosia pollen concentrations were negatively correlated with rainfall in several studies (Barnes et al., 2001), while in others, no statistically significant correlations were found (Bartkova-Scevkova, 2003). It was established that the relation between higher temperatures and higher pollen concentrations is stronger in urban than in rural locations (Ziska et al., 2003). Aerobiological monitoring indicates that after release, air pollen can be transported on the order of 10-1000 km (Wozniak and Steiner, 2017). Long-range pollen transport may have an important effect on local pollen concentrations (Kaplan et al., 2003; Makra et al., 2010; Šaulienė and Veriankaitè, 2012; Celenk and Malyer, 2017). As an example, for Szeged, Hungary, annual pollen amount transported by the atmospheric circulation is $27.8 \%$ of the annual total pollen. From this quantity, $7.5 \%$ is added to (due to transport), while $20.3 \%$ is subtracted from (e.g. because of wash-out by frontal rainfalls going towards Szeged) local sources (Makra et al., 2016).

Statistical methods used in this research were complementary, since they described the various influences of meteorological factors on the dynamic of pollen concentrations. We can consider that the 
correlations identified as statistically significant are not consistent enough. In this study, multiple regression analysis was found to be a valuable technique for exploring and identifying the meteorological parameters closely associated with Ambrosia pollen concentrations (Ianovici et al., 2015). For Ambrosia, the multiple linear regressions with statistically valid parameters varied with the period of presence of pollen (FY, SSD, PD, MPS) and the analysed year. The air temperature was the meteorological variable that influenced the pollen concentrations the most. Relative humidity also showed to have some effect on the dynamics of pollen concentrations present in ambient air. The values of the coefficients of determination obtained during the 2000-2010 period indicates that the dynamic of these pollen concentrations can be associated to other factors such as the different stages of vegetative development of plants. Obviously, pollen release and emission depend on the dehiscence of the male flowers. Anther dehiscence is sensitive to abiotic stress in the environment (Franchi et al., 2007). The stomium opening of anther seems to be a programmed event but the wall outward bending is much more dependent on the environment (Carrizo García et al., 2006). Former studies on excised floral organs of Ambrosia showed that the opening of flowers is controlled by the relative humidity and temperature (Bianchi et al., 1959). Positive significant relationship with daily maximum temperature may be explained by anthers dehiscence and pollen grains release when walls of anthers are dehydrated. This dehydration process is facilitated by the maximum temperatures (Makra et al., 2012).

When the relative humidity is favourable, a gradual increase in the daily mean temperature can intensify vegetative and generative functions, which can lead to increased pollen concentrations (Gioulekas et al., 2004). When the relative humidity values are low, excessive increases in average temperature values may slow down or inhibit pollination. Under these conditions, the plants invest resources in limiting water losses, to the detriment of the generative functions. This may be the explanation for which the daily mean temperature showed inverse association with Ambrosia pollen concentrations (Makra et al., 2012).

In our study, relative humidity was inversely associated with the Ambrosia pollen concentrations. It is accepted that the pollen release and emission is associated with shrinkage and rupture of anthers at low relative humidity. On the other hand, the higher relative humidity may stop or delays the opening of pollen sacks (Bianchi et al., 1959). More than that, humid air makes pollen grains stick together, which contributes to this inverse association (Kozlowski and Pallardy, 2002; Gioulekas et al., 2004).

In this study, the role of quantities of precipitations in Ambrosia pollen concentrations is not clear. Rainfall is not associated with daily pollen concentrations (except MPS for 2009). It is known that rainfall is followed by a temperature drop. Some researchers consider that the involvement of heavy rainfall is complex and could decrease pollen concentrations (Fornaciari et al., 1992; Galan et al., 2000; Hernandez-Ceballos et al., 2011; Makra et al., 2012).

It is obvious that the release of allergenic pollen of Ambrosia depends both on weather variables and phyto-physiological status of plants. Generally, time dependent daily pollen concentrations are influenced by numerous underlying processes: genetic attributes of taxa, soil type and location specific nutrient availability, land use changes, the characteristics of the root zone, resuspension or disruption of the pollen grains, longrange pollen transport, pollen grains as condensation nuclei etc (Matyasovszky et al., 2015). By several orders of magnitude more pollen grains were found at ground level when Ambrosia pollen were collected over an experimental created source (Šikoparija et al., 2018). Also, air pollution and climate change could influence pollen morphology and could increase the aggressiveness of allergens (Ianovici et al., 2008; Zhao et al., 2016). Ambrosia plants have been found to produce more pollen as the CO2 levels increase (Ziska and Caulfield 2000; Ziska et al., 2003; Singer et al., 2005). However, the level of pollen concentrations and the pattern of pollen seasons, can also be influenced by human activity (Kasprzyk and Walanus, 2010).

Ambrosia artemisiifolia is a highly prevalent taxon in the Western Plain (which is part of the Pannonian Plain) (Juhász et al., 2004; Zink et al., 2011). Ambrosia in western region of Romania discharges more pollen grains into the atmosphere than all other allergenic plants (Ianovici and Sîrbu, 2007). For example, Ambrosia 
was the best-represented non-arboreal pollen type throughout the 2009 study period (an average of $19.83 \%$ of the annual total) (Ianovici et al., 2013a). At the same time, evaluations of monosensitization patients (51.44\%) were showed that Ambrosia pollen is principal outdoor aeroallergen (Ianovici et al., 2013a). The recent data confirm that Ambrosia pollen is an important allergen for the Southeast region of Romania (Popescu and Tudose, 2011; Leru et al., 2019). Moreover, Ambrosia pollen was the most important aeroallergen in all of the urban areas sampled during August 2008 (Timisoara, Cluj-Napoca, Bucuresti, Brasov) (Ianovici et al., 2013b). In these big cities of Romania, the number of days exceeding the threshold value $20 \mathrm{~g} / \mathrm{m}^{3}$ (Jäger, 1998) was high: 29 for Timişoara, 25 for Bucharest, 19 for Cluj-Napoca, and 12 for Brasov. In Timişoara and Bucharest, the probability of becoming exposed to high concentrations of Ambrosia pollen and airborne fungal spores (Cladosporium and Alternaria) at the same time is high in August. Anthesis of flowers is prolonged till the beginning of October, along with that of plants belonging to other taxa such as Poaceae, Artemisia and Chenopodiaceae/Amaranthaceae. Furthermore, Ambrosia's pollen can play a role together with Artemisia's pollen on allergic respiratory symptoms, which seen in August-September period (Biçakçi and Tosunoğlu, 2015).

A. artemisiifolia produces very large amounts of pollen and even small populations can be responsible for an increased pollen exposure. Analysis of the data indicated that Ambrosia pollen concentrations in Timisoara vary from year to year. In 1999, the atmosphere did not appear to be biologically polluted because of the pollen produced by $A$. artemisiifolia. The preliminary study for that year indicated a SPI with 722 pollen grains (Faur et al., 2001). In cluster B which was identified in the present study (covering the years 2006, 2008, 2009, 2010), the average SPI was 5912 pollen grains. Time series analysis can reveal trend estimation in our data observed and predict future trends. In our opinion, the rising trend of the seasonal pollen index reflects the expansion of Ambrosia populations. It is important to emphasize that stable populations are identified in all parts of Romania (Ianovici, 2011).

August and September were the months with the highest daily Ambrosia pollen concentrations during the study period. This fact confirms the results received by Makra et al. (2004) and Makra et al. (2005). They received that, based on two analyses, the most extreme ragweed pollen load at Szeged, Hungary occurs between August 16 - September 13 (Makra et al., 2014) or between August 20 - September 11 (Makra et al., 2005). This comparison confirms our result with the physical background that the two cities, Timisoara, Romania and Szeged, Hungary are located only $120 \mathrm{~km}$ from each other, both are found in the Pannonian Plain and have the same climate, which is of Köppen Cf climate zone (temperate-warm climate with an almost even distribution of precipitation; Köppen, 1931), or Trewartha's D.1 climate zone (continental climate with long warm season; Trewartha, 1943).

This highly successful pioneer species is adapted to low nutrient environments. The species is both a weed colonizing crops and a ruderal plant developing in open disturbed habitats (such as roadsides, or riverbanks) (Fumanal, 2006). They occur in stubble fields, especially in abandoned places around settlements. The change in land use in Romania was important from the year 1990 until to the year 2000. In this time many fields were abandoned (Ianovici, 2017). Subsequent, the main Ambrosia infested areas were the construction sites, the new residential places with deficient infrastructure and some cultivated land. In the specialized literature it is mentioned that highly vigorous individuals and tolerance of herbivory are two relevant factors explaining the invasion success (Gard et al., 2011; Bonini et al., 2016). On the other hand, Ambrosia has been shown to respond favourably to warming and nitrogen addition (Essl et al., 2009). Some results confirmed that water supply plays important role in its invasivity. In combination with disturbance and other environmental stressors which decrease the competition intensity, Ambrosia might further spread into more productive environments (Leskovsek et al., 2012). The explosive spread could be facilitated by arbuscular mycorrhizal fungi (Fumanal et al., 2006). Another very important aspect is that common ragweed has developed resistance to linuron, S-triazine herbicides and many Group 2 herbicides (Saint-Louis et al., 2005). Invasiveness and high plasticity may be related to the germination behaviour of seeds. For example, the seeds from roadside soils is 
better adapted to the high salinity concentrations than seeds from agricultural field populations (DiTommaso, 2004).

The potential area of Ambrosia artemisiifolia distribution is at latitudes of $50^{\circ}-55^{\circ} \mathrm{N}$. These borders could enlarge because of acclimatization in new regions or reduce due to control and quarantine measures. We hope that the control measures recently adopted in Law 62/2018 against Ambrosia will reduce the invasive plants populations and consequently will decrease the atmospheric pollen load (Leru et al., 2014; Leru et al., 2019). Uncontrolled spread of this invasive plant all over the country is a serious threat to human health. This information is important both in relation to the forecasting of Ambrosia pollen concentrations in the ambient air but also in the design of mitigation strategies because effective strategies vary with the distribution and abundance of plants. A study like this has never been taken before for this long period and this invaded area.

\section{Conclusions}

This study has an important contribution for identification of levels of Ambrosia artemisiifolia pollen in Romania. The data from the entire 10-year study were analysed. Pearson's correlation test and multiple regression analyse were employed to determine the degree of dependence between the pollen concentrations and meteorological conditions. The Ambrosia pollen load of Timisoara is most important between 15 August - 15 September. Our data confirm that Ambrosia pollen is actually a major allergen for the urban environment and for the Western region of Romania also. A longer monitoring period and correlation with health data from allergists are needed. The aerobiological monitoring of this aeroallergen may be useful for the local and national authorities, the clinicians, the patients, and the general public in the Romania. Beyond the certain influences

of the meteorological factors, our data illustrate that there has been a gradual increase in pollen concentrations from year to year. It can be stated that the rising trend of the seasonal pollen index reflects the expansion of Ambrosia populations.

\section{Acknowledgements}

This research received no specific grant from any funding agency in the public, commercial, or not-forprofit sectors.

\section{Conflict of Interests}

The authors declare that there are no conflicts of interest related to this article.

\section{References}

Barnes C, Pacheco F, Landuyt J, Hu F, Portnoy J (2001). Hourly variation of airborne ragweed pollen in Kansas City. Annals of Allergy, Asthma \& Immunology 86:166-171. DOI:10.1016/S1081-1206(10)62686-5

Bartkova-Scevkova J (2003). The influence of temperature, relative humidity and rainfall on the occurrence of pollen allergens (Betula, Poaceae, Ambrosia artemisiifolia) in the atmosphere of Bratislava (Slovakia). International Journal of Biometeorology 48:1-5. https://doi.org/10.1007/s00484-003-0166-2

Bianchi DE, Schwemmin DJ, Wagner JWH (1959). Pollen release in the common ragweed (Ambrosia artemisiifolia). Botanical Gazette 120:235-243. https://www.jstor.org/stable/2473311 ?seq=1

Biçakçi A, Tosunoğlu A (2015). Allergenic Ambrosia (ragweed) pollen concentrations in Turkey. Asthma Allergy Immunology 13:33-46. doi: 10.5578/aai.8529 
Bilińska D, Skjøth CA, Werner M, Kryza M, Malkiewicz M (2017). Source regions of ragweed pollen arriving in southwestern Poland and the influence of meteorological data on the HYSPLIT model results. Aerobiologia 33(3):315326. https://doi.org/10.1007/s10453-017-9471-9

Birsan MV, Marin L, Dumitrescu A (2013). Seasonal changes in wind speed in Romania, Romanian Reports in Physics 65(4):1479-1484.

Birsan MV (2015). Trends in monthly natural streamflow in Romania and linkages to atmospheric circulation in the North Atlantic. Water Resources Management 29(9): 3305-3313. https://doi.org/10.1007/s11269-015-0999-6

Birsan MV, Micu DM, Nita IA, Mateescu E, Szép R, Keresztesi Á (2019). Spatial-temporal changes in annual temperature extremes over Romania (1961-2013). Romanian Journal of Physics 64(7-8): 816.

Birsan MV, Nita IA, Craciun A, Sfîcă L, Radu C, Szép R, ... Micheu MM (2020). Observed changes in mean and maximum monthly wind speed over Romania since AD 1961. Romanian Reports in Physics 72(1):702.

Bonini M, Sikoparija B, Prentovic M, Cislaghi G, Colombo P, Testoni C (2016). A follow-up study examining airborne Ambrosia pollen in the Milan area in 2014 in relation to the accidental introduction of the ragweed leaf beetle Ophraella communa. Aerobiologia 32(2):371-374. https://doi.org/10.1007/s10453-015-9406-2

Busuioc A, Birsan MV, Carbunaru D, Baciu M, Orzan A (2016). Changes in the large-scale thermodynamic instability and connection with rain shower frequency over Romania: verification of the Clausius-Clapeyron scaling. International Journal of Climatology 36:2015-2034. https://doi.org/10.1002/joc. 4477

Cariñanos P, Emberlin J, Galan C, Domingues-Vilches E (2000). Comparison of two pollen counting methods of slides from a Hirst type volumetric trap. Aerobiologia 16:339-346. https://doi.org/10.1023/A:1026577406912

Carrizo García C, Nepi M, Pacini E (2006). Structural Aspects and ecophysiology of anther opening in Allium triquetrum. Annals of Botany 97:521-527.

Celenk S, Malyer H (2017). The occurrence of Ambrosia pollen in the atmosphere of northwest Turkey: investigation of possible source regions. International Journal of Biometeorology 61:1499-1510. https://doi.org/10.1007/s00484$017-1328-y$

Chen K W. Marusciac L, Tamas P T, Valenta R, Panaitescu C (2018). Ragweed pollen allergy: burden, characteristics, and management of an imported allergen source in Europe. International Archives of Allergy and Immunology https://doi.org/10.1159/000487997

Comtois P (1998). Statistical analysis of aerobiological data. In: Mandrioli P, Comtois P, Levizzani V (Eds.) Methods in Aerobiology. Pitagora Editrice, Bologna.

DiTommaso A (2004). Germination behaviour of common ragweed (Ambrosia artemisiffolia) populations across a range of salinities. Weed Science 52:1002-1009. https://doi.org/10.1614/WS-04-030RI

Dobrinescu A, Busuioc A, Birsan MV, Dumitrescu A (2015). Changes in thermal discomfort indices in Romania and responsible large-scale mechanisms, Climate Research 64(3):213-226. https://doi.org/10.3354/cr01312

Essl F, Dullinger S, Kleinbauer I (2009). Changes in the spatio-temporal patterns and habitat preferences of Ambrosia artemisiifolia during its invasion of Austria. Preslia 81:119-133. http://www.preslia.cz/P092Essl.pdf

Essl F, Biró K, Brandes D, Broennimann O, Bullock JM (2015). Biological flora of the British Isles: Ambrosia artemisiifolia. Journal of Ecology103:1069-1098. https://doi.org/10.1111/1365-2745.12424

Faur A, Ianovici N, Rotundu M (2001). Aerobiologic study on some composites allergen pollen in Timisoara. Proceeding of $4^{\text {rd }}$ International Symposium Regional Multidisciplinary Research (Hungary, Romania, Yugoslavia), Section Biological Sciences, Agriculture and Environment - 16-18 November 2000, Timişoara, 172-177.

Fehér Z, Járai-Komlódi M (1998). A new weather factor predicting airborne pollen concentration: Péczely's macrosynoptic weather types. Aerobiologia 14(2):171-177. https://doi.org/10.1007/BF02694202

Fornaciari M, Bricchi E, Greco F, Fascini D, Giannoni C (1992). Daily variations of Urticaceae pollen count and infl uence of meteoclimatic parameters in East Perugia during 1989. Aerobiologia 8:407-413. https://doi.org/10.1007/BF02272907

Franchi GG, Nepi M, Matthews ML, Pacini E (2007). Anther opening, pollen biology and stigma receptivity in the long blooming species, Parietaria judaica L. (Urticaceae) Flora 202:118-127. https://doi.org/10.1016/j.flora.2006.03.005

Fumanal B, Plenchette C, Chauvel B, Bretagnolle F (2006). Which role can arbuscular mycorrhizal fungi play in the facilitation of Ambrosia artemisiffolia L. invasion in France? Mycorrhiza 17:25-35. https://doi.org/10.1007/s00572-006-0078-1 
Galan C, Alcazar P, Cariňanos P, Garcia H, Dominguez-Vilches E (2000). Meteorological factors affecting daily Urticaceae pollen counts in southwest Spain. International Journal of Biometeorology 43:191-195. https://doi.org/10.1007/s004840050008

García-Mozo H, Yaezel L, Oteros J, Galán C (2014). Statistical approach to the analysis of olive long-term pollen season trends in southern Spain. Science of the Total Environment 473-474:103-109. https://doi.org/10.1016/j.scitotenv.2013.11.142

Gard B, Bretagnolle F, Laitung B (2011). How does common ragweed tolerate insect herbivory? 3rd International Symposium on Weeds and Invasive Plants, Ascona, Switzerland October 2-7.

Gioulekas D, Balafoutis C, Damialis A, Papakosta D, Gioulekas G (2004). Fifteen years' record of airborne allergenic pollen and meteorological parameters in Thessaloniki, Greece. International Journal of Biometeorology 48:128136. DOI: $10.1007 / s 00484-003-0190-2$

Hernandez-Ceballos MA, Garcia-Mozo H, Adame JA, Dominguez-Vilches E, De la Morena, BA (2011). Synoptic and meteorological characterisation of olive pollen transport in Cordoba province (south-western Spain). International Journal of Biometeorology 55:17-34. DOI:10.1007/s00484-010-0306-4

Hirst JM (1952). An automatic volumetric spore trap. Annals of Applied Biology 39:257-265

Ianovici N, Sîrbu C (2007). Analysis of airborne ragweed (Ambrosia artemisiifolia L.) pollen in Timişoara, 2004. Analele Universității din Oradea, Fascicula Biologie XIV:101-108.

Ianovici N (2007). The principal airborne and allergenic pollen species in Timişoara. Annals of West University of Timişoara, ser. Biology 10:11-26.https://biologie.uvt.ro/annals/vol_10/vol_X_11-26_Ianovici.pdf

Ianovici N, Şteflea F, Tilică Dondera P (2008). Date preliminare privind viabilitatea polenului ca bioindicator al calităţii aerului în Timişoara. Annals of West University of Timişoara, ser. Biology 11: 9-14. https://biologie.uvt.ro/annals/fullaccess/vol_XI_9.pdf

Ianovici N (2009). Approaches on the invasive alien taxa in Romania - Ambrosia artemisiifolia (ragweed) I, Annals of West University of Timişoara, ser. Biology 12: 87-104.https://biologie.uvt.ro/annals/fullaccess/vol_XII_87.pdf

Ianovici N (2011). Approaches on the invasive alien taxa in Romania - Ambrosia artemisiifolia (ragweed) II, Annals of West University of Timişoara, ser. Biology 14:93-112. https://biologie.uvt.ro/annals/vol_14/vol_XIV_93$112 \% 20 . p d f$

Ianovici N, Panaitescu Bunu C, Brudiu I (2013a). Analysis of airborne allergenic pollen spectrum for 2009 in Timişoara, Romania, Aerobiologia 29 (1):95-111. https://doi.org/10.1007/s10453-012-9266-y

Ianovici N, Maria C, Răduțoiu MN, Haniş A, Tudorică D (2013b). Variation in airborne fungal spore concentrations in four different microclimate regions in Romania. Notulae Botanicae Horti Agrobotanici Cluj-Napoca 41(2):450457. https://doi.org/10.15835/nbha4129032

Ianovici N, Tudorică D, Șteflea F (2015). Methods of biomonitoring in urban environment: allergenic pollen in Western Romania and relationships with meteorological variables. Annals of West University of Timişoara, ser. Biology 18 (2):145-158.https://biologie.uvt.ro/annals/vol_18_2/AWUTSerBio_December2015_145-158.pdf

Ianovici N (2015). Relation between Poaceae pollen concentrations and meteorological factors during 2000-2010 in Timisoara, Romania. Acta Agrobotanica 68(4):373-381.

Ianovici N (2017). Summer airborne mycoflora of Timisoara (Romania) and relationship to meteorological parameters. Grana 56(6):424-435. https://doi.org/10.1080/00173134.2016.1271823

Juhász M, Juhász IE, Gallovich E, Radišić P, Ianovici N (2004). Last year’s ragweed pollen concentrations in the southern part of the Carpathian Basin. The 11th symposium on analytical and environmental problems, Szeged, pp 339343.

Kaplan A, Sakiyan N, Pinar NM (2003). Daily Ambrosia pollen concentration in the air of Ankara, Turkey (1990--1999). Acta Botanica Sinica 45(12):1408-1412. https://hdl.handle.net/20.500.12628/4978

Kasprzyk I (2008). Non-native Ambrosia pollen in the atmosphere of Rzeszow (SE Poland); evaluation of the effect of weather conditions on daily concentrations and starting dates of the pollen season. International Journal of Biometeorology 52:341-351. DOI:10.1007/s00484-007-0129-0

Kasprzyk I., Walanus A (2010). Description of the main Poaceae pollen season using bi-Gaussian curves, and forecasting methods for the start and peak dates for this type of season in Rzeszów and Ostrowiec Św. (SE Poland). Journal of Environmental Monitoring 12:906-916.

Köppen W (1931). Grundriss der Klimakunde [The basics of the climate]. De Gruyter \& Co, Berlin (in German) 
Kozlowski TT, Pallardy SG (2002). Acclimation and adaptive responses of woody plants to environmental stresses. Botanical Review 68:270-334. https://doi.org/10.1663/0006-8101(2002)068[0270:AAAROW]2.0.CO;2

Leru PM, Matei D, Ianovici N (2015). Health impact of Ambrosia artemisiifolia reflected by allergists practice in Romania. A questionnaire - based survey, Annals of West University of Timişoara, ser. Biology 18(1) :43-54.https://biologie.uvt.ro/annals/vol_18_1/AWUTSerBio_June2015_43-54.pdf

Leru PM, Eftimie AM, Anton VF, Thibaudon M (2019). Five-year data on pollen monitoring, distribution and health impact of allergenic plants in Bucharest and the Southeastern Region of Romania. Medicina 55:140. https://doi.org/10.3390/medicina55050140

Leskovsek R, Eler K, Batric F, Simoncic A (2012). The influence of nitrogen, water and competition on the vegetative and reproductive growth of common ragweed (Ambrosia artemisiffolia L.). Plant Ecology 213:769-781. https://doi.org/10.1007/s11258-012-0040-6

Lo F, Bitz CM, Battisti DS, Hess JJ (2019). Pollen calendars and maps of allergenic pollen in North America. Aerobiologia 35:613-633. https://doi.org/10.1007/s10453-019-09601-2

Makra L, Juhász M, Béczi R, Borsos E (2005). The history and impacts of airborne Ambrosia (Asteraceae) pollen in Hungary. Grana 44(1):57-64

Makra L, Juhász M, Borsos E, Béczi R (2004). Meteorological variables connected with airborne ragweed pollen in Southern Hungary. International Journal of Biometeorology 49(1):37-47.

Makra L, Santa T, Matyasovszky I, Damialis A, Karatzas K (2010). Airborne pollen in three European cities: Detection of atmospheric circulation pathways by applying three-dimensional clustering of backward trajectories. Journal of Geophysical Research 115:D24220.

Makra L, Matyasovszky I, Hufnagel L, Tusnady G (2015). The history of ragweed in the world. Applied Ecology and Environmental Research 13(2):489-512. https://doi.org/10.15666/aeer/1302_489512

Makra L, Matyasovszky I, Tusnády G, Wang YQ, Csépe Z, Bozóki Z, ... Thibaudon M (2016). Biogeographical estimates of allergenic pollen transport over regional scales: common ragweed and Szeged, Hungary as a test case. Agricultural and Forest Meteorology 221:94-110.

Manea A, Birsan MV, Tudorache G, Cărbunaru F (2016). Changes in the type of precipitation and associated cloud types in Eastern Romania (1961-2008). Atmospheric Research 169:357-365.

Matyasovszky I, Makra L, Csépe Z, Sümeghy Z, Deák ÁJ (2015). Plants and past weather: a study for atmosperic pollen concentrations of Ambrosia, Poaceae and Populus. Carpathian Journal of Earth and Environmental Sciences 10 (1):183-193. https://doi.org/10.1007/s00704-014-1280-2

Mihai G, Birsan MV, Dumitrescu A, Alexandru A, Mirancea I, Ivanov P, Daia M (2018a). Adaptive genetic potential of European silver fir in Romania in the context of climate change, Annals of Forest Research 61(1):95-108. https://doi.org/10.15287/afr.2018.1021

Mihai G, Mirancea I, Birsan MV, Dumitrescu A (2018b). Patterns of genetic variation in bud flushing of Abies alba populations, iForest 11(2):284-290. https://doi.org/10.3832/ifor2314-011

Nilsson S, Persson S (1981). Tree pollen spectra in the Stockholm region (Sweden), 1973-1980. Grana 20:179-182. https://doi.org/10.1080/00173138109427661

Peternel R, Čulig J, Srnec L, Mitić B, Vukušić I (2005). Variation in ragweed (Ambrosia artemishfolia L.) pollen concentration in central Croatia, 2002-2003. Annals of Agricultural and Environmental Medicine 12:11-16.

Peternel R, Čulig J, Hrga I, Hercog P (2006). Airborne ragweed (Ambrosia artemisiifolia L.) pollen concentrations in Croatia, 2002-2004. Aerobiologia 22:161-168. https://doi.org/10.1007/s10453-006-9028-9

Piotrowska K, Kubik-Komar A (2012). A comparative analysis of Poaceae pollen seasons in Lublin (Poland), Acta Agrobotanica 65 (4):39-48. https://doi.org/10.5586/aa.2012.020

Popescu FD, Tudose AM (2011). Ambrosia pollen sensitization in allergic rhinitis patients from the central part of the Romanian Plain. Romanian Journal of the Rhinology 1(1):26-30. https://pdfs.semanticscholar.org/97e9/0354a7690e4093dd5f18917b3c53b2f24ea8.pdf?.ga=2.50859433.1288749 674.1585118719-1889325105.1565758675

Puc M (2006). Ragweed and mugwort pollen in Szczecin, Poland. Aerobiologia 22:67-78. https://doi.org/10.1007/s10453005-9010-y 
Ritenberga O, Sofiev M, Siljamo P, Saarto A, Dahl A (2018). A statistical model for predicting the inter-annual variability of birch pollen abundance in Northern and North-Eastern Europe. Science of the Total Environment 615:228239. DOI:10.1016/j.scitotenv.2017.09.061

Saint-Louis S, Ditommaso A, Watson AK (2005). A Common Ragweed (Ambrosia artemisiifolia) Biotype in Southwestern Quebec Resistant to Linuron. Weed Technology 19:737-743. DOI: https://doi.org/10.1614/WT04-276.1

Šaulienè I, Veriankaité L (2012). Analysis of high allergenicity airborne pollen dispersion: common ragweed study case in Lithuania. Annals of Agricultural and Environmental Medicine 19(3):415-419. https://pdfs.semanticscholar.org/94f0/2aaa00c84ed566530d4alae97476318a6fdl.pdf?_ga=2.38742051.1288749 674.1585118719-1889325105.1565758675

Sikoparija B, Skjøth C, Celenk S, Testoni C, Abramidze T (2017). Spatial and temporal variations in airborne Ambrosia pollen in Europe. Aerobiologia 33(2):181-189. https://doi.org/10.1007/s10453-016-9463-1

Šikoparija B, Mimić G, Panić M, Marko O, Radišić P (2018). High temporal resolution of airborne Ambrosia pollen measurements above the source reveals emission characteristics. Atmospheric Environment 193:13-23. https://doi.org/10.1016/j.atmosenv.2018.08.040

Skjøth CA, Smith M, Sikoparija B, Stach A, Myszkowska D (2010). A method for producing airborne pollen source inventories: An example of Ambrosia (ragweed) on the Pannonian Plain. Agricultural and Forest Meteorology 150:1203-1210. https://doi.org/10.1016/j.agrformet.2010.05.002

Smith M, Cecchi L, Skjøth CA, Karrer G, Šikoparija B (2013). Common ragweed: a threat to environmental health in Europe. Environment International 61:115-126. https://doi.org/10.1016/j.envint.2013.08.005

Štefanić E, Kovačević V, Lazanin Ž (2005). Airborne ragweed pollen concentration in north-eastern Croatia and its relationship with meteorological parameters. Annals of Agricultural and Environmental Medicine 12:75-79. http://www.aaem.pl/Annual-variation-of-airborne-pollen-in-the-city-of-Vinkovci-northeasternCroatia, 90383,0,2.html

Stepalska D, Myszkowska D, WoŁek J, Piotrowicz K, ObtuŁowicz K (2008). The influence of meteorological factors on Ambrosia pollen loads in Cracow, Poland, 1995-2006. Grana 47(4):297-304. https://doi.org/10.1080/00173130802492849

Stjepanović B, Svečnjak Z, Hrga I, Večenaj A, Šćepanović M et al. (2015)._Seasonal variation of airborne ragweed (Ambrosia artemisiifolia L.) pollen in Zagreb, Croatia. Aerobiologia 31:525-535. https://doi.org/10.1007/s10453015-9384-4

Vázquez LM, Galán C, Dominguez-Vilches E (2003). Influence of meteorological parameters on Olea pollen concentrations in Cordoba (South-western Spain). International Journal of Biometeorology 48: 83-90. https://doi.org/10.1007/s00484-003-0187-x

Trewartha GT (1943). An introduction to weather and climate. McGraw-Hill, New York

Wozniak MC, Steiner Al (2017). A prognostic pollen emissions model for climate models (PECM1.0) Geoscientific Model Development 10:4105-4127. https://doi.org/10.5194/gmd-10-4105-2017

Zhang Y, Bielory L, Cai T, Mi Z, Georgopoulos P (2015). Predicting onset and duration of airborne allergenic pollen season in the United States. Atmospheric Environment 103:297-306. https://doi.org/10.1016/j.atmosenv.2014.12.019

Zink K, Vogel H, Vogel B, Magyar D, Kottmeier C (2011). Modeling the dispersion of Ambrosia artemisiifolia L pollen with the model system COSMO-ART. International Journal of Biometeorology. https://doi.org/10.1007/s00484011-0468-8

Ziska LH, Gebhard DE, Frenz DA, Faulkner S, Singer BD (2003). Cities as harbingers of climate change: Common ragweed, urbanization, and public health. Journal of Allergy and Clinical Immunology 111:290-295. https://doi.org/10.1067/mai.2003.53

Ziska L, Knowlton K, Rogers C, Dalan D, Tierney N (2011). Recent warming by latitude associated with increased length of ragweed pollen season in central North America. Proceedings of the National Academy of Sciences 108 (10):4248-4251. https://doi.org/10.1073/pnas.1014107108

Ziska LH, Makra L, Harry SK, Bruffaerts N, Hendrickx M, Coates F, ... Crimmins AR (2019). Temperature-related changes in airborne allergenic pollen abundance and seasonality across the northern hemisphere: a retrospective data analysis. The Lancet Planetary Health 3(3):e124-e131. 
Ianovici N and Birsan M-V (2020). Not Bot Horti Agrobo 48(2)752-769

OPEN ACCESS

(c) (i)

The journal offers free, immediate, and unrestricted access to peer-reviewed research and scholarly work. Users are allowed to read, download, copy, distribute, print, search, or link to the full texts of the articles, or use them for any other lawful purpose, without asking prior permission from the publisher or the author.

License - Articles published in Notulae Botanicae Horti Agrobotanici Cluj-Napoca are Open-Access, distributed under the terms and conditions of the Creative Commons Attribution (CC BY 4.0) License. (c) Articles by the authors; UASVM, Cluj-Napoca, Romania. The journal allows the author(s) to hold the copyright/to retain publishing rights without restriction. 